Original article

\title{
LINKING DISTRUST OF THE PUBLIC SECTOR TO AWARENESS OF COVID-19: THE COVID DISSIDENCE PHENOMENON
}

\author{
Natalya Dmitrieva ${ }^{1}$, Evgeny Styrin², \\ Nicolay Lavrentyev ${ }^{3}$, Ruslan Artamonov ${ }^{4}$
}

${ }^{1,2,3,4}$ National Research University, Higher School of Economics, Moscow, Russia.

E-mail: ${ }^{1}$ nedmitrieva@hse.ru, ${ }^{2}$ estyrin@hse.ru, ${ }^{3}$ nlavrentyev@hse.ru, ${ }^{4}$ reartamonov@hse.ru

\begin{abstract}
In this study, we analyze the correlation between trust in government and official information with individual compliance to recommended measures, and between attitudes to government measures and people's behavior during the Covid-19 pandemic. We identified a group of respondents who refused categorically to believe in the COVID-19 pandemic in Russia - COVID-19 dissidents. They not only deny the pandemic but also refuse to comply with pandemic rules and restrictions. Then, based on seven national samples covering a combined total of 40,700 people in all regions of Russia, we established a link between the level of distrust of the public sector and the level of COVID-19 dissidence by means of linear regression.

We proved that COVID-19 dissidents do not trust official statistics and believe in low infection risks. They provide low evaluation of the medical aid quality which leads to underestimation of the risk of being infected and COVID-19 compliance rules. We recommend governments consider restoring citizens' trust as one of the priorities in fighting the pandemic, alongside battling misinformation that feeds conspiracy beliefs. The level of public trust in government decisions is a critical factor that speeds up mass vaccinations and contributes to a quick exit from the pandemic crisis.
\end{abstract}

Keywords: Trust in government, distrust of the public sector, COVID dissidents, generalized social trust.

For citation Dmitrieva, N., Styrin, E., Lavrentyev, N. and Artamonov, R. (2021) 'Linking distrust of the public sector to awareness of COVID-19: The COVID dissidence phenomenon', Public Administration Issues, 6 (Special Issue II, electronic edition), pp. 24-48 (in English). DOI: 10.17323/1999-5431-2021-0-6-24-48.

Acknowledgements. The article was prepared within the framework of the HSE University Basic Research Program.

JEL Classification: I1, I18. 


\section{Introduction}

The theoretical literature offers a variety of approaches to and classifications of trust, depending on whether trust is conceived of in economic, political, psychological or social terms. The works of Francis Fukuyama, Piotr Sztompka, Adam Seligman and others lay the foundation for the study of various aspects of social trust. In this study, we rely on the sociological theories of trust as social capital, and we view this phenomenon in the context of a risk society.

In a risk society, the past loses its ability to determine the present (Beck, 2000), and trust plays a key role in containing risk and mitigating uncertainty. Trust is a "prosthesis that people need in a risk society" (Sztompka, 2012, p. 112). In this study, we drew on Sztompka's idea that distrust is the "mirror image of trust," involving negative expectations of others' future actions, whereas lack of trust is a transitional, intermediate stage in the process of building or losing trust. Following Sztompka, we treat distrust as a specific position, not merely a lack of trust. We also adopted Seligman's understanding of trust (2002) as a form of generalized exchange that is acquired and used only by a whole group and, in modern public relationships, forms the basis of solidarity, creating, in turn, a base for social capital. At the same time, "the reduction of trust in a society will require a more intrusive, rule-making government to regulate social relations" (Fukuyama, 2008, p. 588). For this reason, we regard trust as a matter of exceptional importance and relevance during the COVID-19 pandemic.

Trust in government has long been a subject of study for scholars (Bok, 1997; Levy and Stoker, 2000; Kim, 2005). Trust in government is not analogous to personal trust (Aitalieva, 2018). Uslaner (2008) notes that trust in government is different from trust in people and is about government performance and the popularity of political leaders. Government creates a legal framework, standards and administrative practices, all of which can be considered independent objects of trust. Citizens may have different attitudes to different types of government activities and trust or distrust them, and these relationships may change over time. Trust in public institutions can be evaluated indirectly through the observance of laws and regulations. Christensen and Laegreid (2005) found that people who have a high level of trust in one government institution are able to trust all the others. They also say that the higher the level of satisfaction with public services, the more trust people have in government institutions.

Government as a set of institutions is an interesting subject of institutional trust studies (Bachman and Inkpen, 2011), posing questions of trust in internal and external institutional processes, trust monitoring and measurement. However, Nooteboom (2007) states that "for institutions to form a basis for trust in people (institution based trust), one must have trust in those institutions (institutional trust)" (p. 30). Although conceptually institutional trust can be considered as a single structure, trust in specific institutions, such as the police, courts, parliament or banks, is of much greater practical importance. The World 
Values Survey ${ }^{1}$ WVS) is an international research program that contains a wide range of questions about trust between various groups of people and institutions. However, Nooteboom (2007) recommends: "For measurement, in surveys, and analysis, and for cross-country comparisons, one should be aware of distinctions between objects of trust (people, firms, institutions), aspects of behavior (competence, intentions), the limits of trust (due to pressures of survival), and the distinction between reliability, which includes control, and trustworthiness, which goes beyond control" (p. 48).

In the last few decades, trust in governments has been in decline. Because trust in institutions depends on competence and values, the information provided to the public should allow citizens to correct their beliefs about how reliable, responsive and efficient the government is. Trust allows citizens to evaluate the government's integrity, openness, and fairness (OECD, 2017b). Grimmelikhuijsen (2012) distinguishes trust between three dimensions: competence, benevolence, and honesty. Alessandro et al. (2021) built a global index (Trust in Government) on four intermediate indexes (Competence, Benevolence, Honesty, and Confidence).

Trust in government cannot exist without transparency, i.e. transparency of internal government activities and decision-making for an external observer who can obtain the necessary information (Grimmelikhuijsen et al., 2013). Rainey (1997) points out that the public often has incorrect information and a biased perception of government activities. In the age of digital technology, information transparency becomes a key dimension of transparency that can be delivered via official government resources and social media. Information transparency for citizens is characterized by accuracy of information, provision of information to the public, the right to access information, and reliable and verifiable sources of information (Cullier and Piotrowsky, 2009; Jaeger and Bertot, 2010).

A key purpose of government information policy is to produce an "informed citizenry" by means of digital technologies and the Internet (Grimmelikhuijsen et al., 2013). But if such a policy is ineffective or lacking, especially in times of crisis, the vacuum is filled by all sorts of unsubstantiated rumors and speculation, serving to further undermine trust in official information and the government. Tolbert and Mossberger (2006) demonstrated a direct link between the use of government websites and the level of public confidence in government. Michener and Bersch (2013) formulated the requirements for government information that can help produce informed citizens. Information should be verifiable, simple, comprehensible and accessible so that citizens can easily find it, understand it and reach unambiguous conclusions. Generally speaking, the accuracy of information influences the level of trust (Buerhoff and Vornefeld, 2016). COVID-19 has demonstrated this to a large extent. When government agencies promptly distribute information to the public through social media channels about the measures taken against COVID-19, the positive perception of the government's response

1 World Values Survey. URL: https://www.worldvaluessurvey.org/WVSContents.jsp (accessed 30 September 2021). 
by citizens during the crisis increases and leads to a higher level of trust (Mansoor, 2021). Using social networks for civic engagement has a significant positive effect on the propensity to trust, and this trust leads to an increase in trust in institutions (Warren et al., 2014; Ticlău, Hintea and Andrianu, 2020).

Trust has become a key factor during the COVID-19 pandemic, both in slowing the spread of the novel coronavirus infection and in helping countries make a faster recovery from the attendant economic crisis. According to the 2020 Edelman Trust Barometer, ${ }^{2}$ current world trends in the level of trust are such that people in many countries view government bodies and governments in general as incompetent, unethical and untrustworthy. Moreover, despite a strong global economy and near full employment at the end of 2019, people trusted none of the four analyzed institutions: government, business, non-governmental organizations and the mass media. According to the 2021 Edelman Trust Barometer ${ }^{3}$ the COVID-19 pandemic has accelerated the erosion of trust around the world. For example, in the last six months of 2020, the level of trust in governments worldwide has decreased by $8 \%$. The most noticeable is the drop in confidence among Chinese citizens: minus 18 points since May 2020. Trust in any sources of information over the last year of the COVID-19 pandemic has fallen to a record low (search engines $-56 \%$, minus $6 \%$, social networks $-35 \%$, minus $5 \%$ ).

In the midst of the global COVID-19 pandemic, society's level of trust is directly related to both past and future actions of government institutions. In the current situation, trust depends crucially on the set of measures that authorities develop and implement to prevent, treat and slow the spread of the infection as well as on support for the population and business. Another key factor in relations between government and society is work to raise public awareness of various processes going on in the country.

Seven sociological surveys, conducted in Russia in March-August 2020 and based on a representative sampling, identified a stable group of COVID dissidents - people who are less inclined to agree with the restrictions imposed, less willing to comply with lockdown measures and more critical of the actions taken by local and national government. An international comparison between the level of trust and the spread of COVID-19 has shown that such trends are not limited to Russia. The authors compared data on the global spread of COVID-19 with the findings of the 2020 Edelman Trust Barometer and found that the speed of transmission and length of lockdowns in the first wave of the pandemic correlated with the level of trust in national governments.

Our study focuses on COVID dissidents, who deny the pandemic despite the wide dissemination of information on COVID-19, the growing number of cases, the rising death toll, and the measures taken by the government. We look at how trust in government impacts the compliance with anti-COVID measures.

This article is structured as follows: First, we characterize trust as well as distrust of the public sector. Second, we describe the base, data and methodology

2 Edelman Trust Barometer 2020. URL: 2020 Edelman Trust Barometer | Edelman (accessed 30 September 2021).

3 Edelman Trust Barometer 2021. URL: 2021 Edelman Trust Barometer | Edelman (accessed 30 September 2021). 
of our study. Third, we present our key findings. Finally, we formulate our conclusions and make recommendations for further research.

\section{Conceptual framework}

Many scholars have investigated the influence of government measures on the spread of the COVID-19 pandemic. In general, the measures taken by governments belong to two main types: one concentrates on strengthening the capacity of the hospital system, such as setting up temporary hospitals; the other targets reducing the probability of contracting the virus, such as a lockdown (Alfano and Ercolano, 2020; Achuo, 2020). We studied the link between citizens' trust in government and support for its measures to control COVID-19. In each country, of course, the level of public trust in government is influenced by a wide variety of social, political, economic and other factors. However, our review of relevant research has shown that these are similar factors.

First, by analyzing existing academic studies, we found that individual compliance with the recommended measures is influenced by many economic, sociopolitical, and psychological factors (Bish and Michie, 2010). Previous outbreaks of the pandemic in the world have shown that lack of trust can lead to refusal to comply, which leads to increased difficulties in fighting the disease. Trust in government is a strong determinant of preventive behaviors during a pandemic (Freimuth et al., 2014). Factual knowledge provision about government performance outcomes and intentions could be an important way of increasing citizens' trust in government (Grimmelikhuijsen, 2012).

Second, we compared data on the level of trust in countries covered in the 2020 Edelman Trust Barometer ${ }^{4}$ with international statistics on the number of cases ${ }^{5}$ on the first, tenth and twentieth days of lockdown periods in the countries selected for analysis and confirmed a correlation that the lower the level of trust in public institutions, the lower the level of compliance with lockdown restrictions (rules).

Using data on restrictions (lockdown measures) ${ }^{6}$, we measured the spread of COVID-19 in relation to the introduction and lifting of restrictions (lockdown measures) in each of the analyzed countries. It should be noted that, in introducing restrictions to slow and/or prevent the spread of COVID-19, the analyzed countries did not do so in a uniform manner, but at different times and in stages, depending on the number of cases nationally and internationally, the economic and social situation and other factors. Detailed data are provided in Appendix A.

The 2020 Edelman Trust Barometer bases its assessment of the level of trust in relations between government and society on two criteria - competence (delivering on promises) and ethical behavior (doing the right thing for society) -

\footnotetext{
${ }^{4}$ Edelman Trust Barometer 2020.

5 Worldometer. Coronavirus statistics. URL: https://www.worldometers.info/coronavirus/ (accessed 30 September 2021).

${ }_{6}$ Global Covid-19 Lockdown Tracker. URL: https://auravision.ai/covid19-lockdown-tracker/ (accessed 30 September 2021).
} 
and the authors of this study thus hypothesized that a high level of trust in public institutions would promote compliance with government lockdown restrictions, and vice versa: a lower level of trust in government would result in a higher level of non-compliance with lockdown restrictions.

In all of the countries that we looked at, restrictions had a positive effect in terms of slowing the spread of COVID-19: the rate of growth in the number of cases was substantially lower after restrictions were lifted. However, despite the fact that the duration of lockdown measures differed from country to country, countries with a high trust rating showed average rates of growth that were half what they were in countries with a low rating on the tenth and twentieth days after restrictions were lifted. Countries with a higher level of trust saw median growth of $1.6 \%$ and $1.5 \%$ in the number of cases on the tenth and twentieth days after restrictions were lifted, while countries with a low level of trust saw $3.5 \%$ and $2.9 \%$, respectively.

Moreover, lockdown measures lasted longer on average in countries in the first group (67 days) than in countries in the second group (47 days). This may indicate an understanding that lockdown measures needed to be extended in countries with a low level of trust because citizens did not scrupulously comply with government restrictions for a considerable period of time.

Bargain and Aminjonov (2020) combined three data sources: COVID-19 mobility reports from Google, trust data from the European Social Survey and policy stringency from the Oxford COVID-19 Government Response Tracker. They found out that European regions with high-trust level before COVID-19 crisis demonstrated high and non-linear efficiency of government constraints policy during the crisis.

Third, we analyzed various studies on the relationship between trust in government and official information, attitudes to government measures and people's behavior during the Covid-19 pandemic.

At the beginning of the Covid-19 pandemic, scientists from different countries studied the relationship between public confidence and support for government measures to combat COVID-19. Pre-existing institutional trust affects attitudes towards an emergency response. But researchers have discovered the socalled "crisis effect". For example, in the UK, whilst $52.7 \%$ of respondents said the government was making the right decisions, only $42.3 \%$ thought the government was telling the truth about COVID-19. Generalised mistrust in politics was shared across all groups as a reason for questioning the truthfulness of official information on COVID-19 (Enria et al., 2020).

Mansoor (2021) studied the mechanism of the relationship between the elements of good governance and public confidence in government. He showed through the example of Pakistan that the citizens' perception of government measures on COVID-19 is positively associated with the general trust in government.

Government agencies are responsible for providing information about the outbreak of the virus. Attitudes towards public institutions can influence how people perceive reports about the epidemic and the restrictions imposed.

Alessandro et al. (2021) highlight the importance of active information provision to citizens as a way to increase transparency. If citizens find out about 
the deception, they will no longer trust the information provided by the government, and the value of any subsequent signals will disappear. The provision of high-quality and objective information through social networks strengthens this connection (Mansoor, 2021). American scholars investigated the level of public trust in various sources of information about COVID-19, depending on the categories of general health, age, place of residence, as well as the quality of compliance with recommended measures to prevent the spread of COVID-19 (Ipsen et al., 2021).

A number of researchers from different countries have studied the relationship between different types of conspiracy theories about COVID-19 and defensive behavior.

On the one hand, these studies have demonstrated a relationship between the approval of unreasonable beliefs about COVID-19 and a decrease in compliance with public health recommendations (Allington et al., 2020; Oleksy et al., 2021). Wirawan et al. (2021) showed that the relationship between conspiracy beliefs and restriction-related behavior is mediated by political trust, a preference for saving the economy, and a preference for saving lives. On the other hand, some studies find no significant link between conspiracy theories and compliance with preventive measures, which can be explained by significant differences between countries and assessment tools. For example, researchers from China proved a positive statistically significant relationship between trust and excessive preventive behavior only among people with a low level of knowledge about COVID-19 (Min et al., 2020).

To analyze the correlation between COVID dissidence and distrust of the public sector, we applied the model used by Porumbescu (2016) to analyze how the use of social networks and websites is linked to trust in government. This partly determined our choice of theoretical sources. Porumbescu based his measurement of trust in government on three criteria: citizens' opinion of public sector competence, their opinion of whether the public sector acts in the interests of citizens, and the public sector's truthfulness in living up to its public commitments.

In addition, other confidence factors from the global online survey in 58 countries were analyzed. The results of this study indicate a strong distrust of government (26.6\%), which depends on stringency of public health measures and mental health outcomes and gender (O'Hara et al., 2021).

All other hypotheses are formulated in accordance with this model and presented in Table 2.

\section{Data, measures, research methodology, hypotheses}

\section{Data}

The study consists of seven separate sociological surveys (waves of research) taken by residents of Russia between 18 March and 7 September 2020, involving a programmed online questionnaire. The total research sample included 40,700 people from all 85 constituent entities of the Russian Federation. Detailed information is provided in Table 1. 
Table 1

Research samples by survey (wave)

\begin{tabular}{|l|c|c|c|c|c|c|c|}
\hline & 1st wave & 2nd wave & 3rd wave & 4th wave & 5th wave & 6th wave & 7th wave \\
\hline $\begin{array}{l}\text { Periods } \\
\text { of fieldwork }\end{array}$ & $\begin{array}{c}18-19 \\
\text { March 2020 }\end{array}$ & $\begin{array}{c}4-5 \\
\text { April 2020 }\end{array}$ & $\begin{array}{c}18-20 \\
\text { April 2020 }\end{array}$ & $\begin{array}{c}11-12 \\
\text { May 2020 }\end{array}$ & $\begin{array}{c}21-26 \\
\text { May 2020 }\end{array}$ & $\begin{array}{c}13-16 \\
\text { June 2020 }\end{array}$ & $\begin{array}{c}\text { 5-7 Septem- } \\
\text { ber 2020 }\end{array}$ \\
\hline $\begin{array}{l}\text { Sample } \\
\text { (no. of respondents) }\end{array}$ & 1,2 & 3,1 & 11,1 & 7,3 & 7,6 & 7,8 & 9 \\
\hline Women, \% & 54.6 & 54.5 & 59.6 & 53.7 & 55.5 & 54.7 & 53.5 \\
\hline less than 20 years, \% & 8.7 & 3.1 & 4.2 & 3.3 & 3.8 & 2.9 & 2.8 \\
\hline 20-29 years, \% & 16.3 & 12.0 & 17.3 & 11.9 & 14.4 & 11.8 & 9.5 \\
\hline 30-39 years, \% & 19.4 & 22.9 & 25.7 & 22.8 & 24.1 & 22.4 & 22.4 \\
\hline $40-49$ years, \% & 19.7 & 18.8 & 23.7 & 19.0 & 23.0 & 18.8 & 18.4 \\
\hline 50-59 years, \% & 19.6 & 17.6 & 18.0 & 18.4 & 19.6 & 17.5 & 17.3 \\
\hline 60 years and more, \% & 16.2 & 25.5 & 11.0 & 24.5 & 15.0 & 26.5 & 29.5 \\
\hline
\end{tabular}

Source: Compiled by the authors.

During periods of fieldwork, respondents were recruited from among all users of the Russian Internet, using banners, pop-up windows and offers. People who matched the characteristics of the target group were routed to the online questionnaire. Recruitment took place wherever people spend time on the Internet: social networks, news portals, apps and games, search engines, thematic websites, blogs and forums, etc. Respondents were recruited by means of river sampling in proportion to the population of each federal district. Instead of selecting respondents from databases (panels), river sampling is an online research method that involves recruiting Internet users in real time.

River sampling makes it possible to recruit respondents from a variety of social and demographic groups, not just those willing to take a paid survey. By promoting a survey on thematic platforms, researchers obtain a sample that is representative by age, gender and region of Russia.

\section{Measures}

The surveys in each of the seven waves consisted of an average of 25-30 questions, including open-ended questions and socio-demographic questions. There were also filter questions: the answer to one question determined whether the respondent would be asked follow-up questions or not. Questionnaires took an average of no more than fifteen minutes to complete. They were programmed so that no one could take the survey more than once. Each respondent's answers were entered in an electronic database in SPSS format. Data on respondents who did not answer all the questions were excluded from consideration.

The questionnaire was developed using the OECD Guidelines on Measuring Trust and contains international recommendations for the collection, publication and analysis of trust data (OECD, 2017a). 


\section{Research Methodology}

In our study, following Porumbescu's model (2016), citizens' perception of whether the public sector has the required competencies is reflected in the following questions:

- $\quad$ confidence (on scale of 10) that problems caused by the pandemic in Russia will be solved within a month;

- confidence (on scale of 10) that medical institutions in the area where the respondent lives can cope with the flow of patients.

Citizens' perception of whether the public sector acts with their best interests in mind and is committed to their well-being was studied using the following questions:

- $\quad$ attitude (Likert scale) to self-isolation measures;

- $\quad$ assessment (on a scale of 5) of the authorities' efforts to support individuals and the economy during the pandemic.

The third group of questions reflects citizens' perception of whether the public sector is truthful in its dealings and sincere in its attempts to live up to public commitments:

- $\quad$ trust in official statistics on the number of cases in Russia (nominal scale)

There is a special group of questions on changes during the pandemic:

- $\quad$ assessment of the risk (on a scale of 10) that respondents and their families will be infected;

- $\quad$ awareness of infected people in the respondent's environment (nominal scale);

- $\quad$ changes in the respondent's accustomed lifestyle (nominal scale);

- $\quad$ assessment of changes (Likert scale) in the respondent's level of income and expenses;

- $\quad$ assessment (on a scale of 10) of the respondent's adaptation to self-isolation measures;

as well as socio-demographic characteristics: sex, age, economic status, size of community and occupation.

\section{Hypotheses}

Table 2

\section{Summary of hypotheses}

\begin{tabular}{|c|c|}
\hline$(\mathrm{H} 1)$ & $\begin{array}{l}\text { The lower the level of support for (compliance with) government lockdown measures, } \\
\text { the higher the level of COVID dissidence }\end{array}$ \\
\hline$(\mathrm{H} 2)$ & The greater the distrust of official statistics, the higher the level of COVID dissidence \\
\hline (H3) & $\begin{array}{l}\text { The lower the assessment people give of their personal risk of being infected, the higher } \\
\text { the level of COVID dissidence }\end{array}$ \\
\hline$(\mathrm{H} 4)$ & The lower a household's economic status, the higher the level of COVID dissidence \\
\hline (H5) & Young people are more likely to be COVID dissidents \\
\hline (H6) & $\begin{array}{l}\text { COVID dissidents are more likely to live in small communities far from large } \\
\text { metropolitan areas }\end{array}$ \\
\hline
\end{tabular}




\begin{tabular}{|c|l|}
\hline (H7) & Men are more likely than women to be COVID dissidents \\
\hline (H8) & $\begin{array}{l}\text { The less confidence people have that the public sector is competent to deal with the } \\
\text { problems caused by COVID-19, the higher the level of COVID dissidence }\end{array}$ \\
\hline (H8-1) & $\begin{array}{l}\text { The less confidence people have that medical institutions where they live are prepared for } \\
\text { the flow of patients, the greater their distrust of the public sector's competence to control } \\
\text { COVID-19 }\end{array}$ \\
\hline$($ H9) & $\begin{array}{l}\text { COVID dissidents are more likely to be critical of the public sector's efforts to support } \\
\text { individuals and the economy during the COVID-19 pandemic }\end{array}$ \\
\hline (H9-1) & $\begin{array}{l}\text { The more strongly people disagree with self-isolation measures, the lower their } \\
\text { assessment of the public sector's efforts to support individuals and the economy during } \\
\text { the pandemic }\end{array}$ \\
\hline (H9-2) & $\begin{array}{l}\text { The lower the level of people's compliance with self-isolation, the lower their assessment } \\
\text { of the public sector's efforts to support individuals and the economy during the } \\
\text { pandemic }\end{array}$ \\
\hline (H9-3) & $\begin{array}{l}\text { The higher the level of people's adaptation to self-isolation, the higher their assessment } \\
\text { of the public sector's efforts to support individuals and the economy during the } \\
\text { pandemic }\end{array}$ \\
\hline
\end{tabular}

Source: Compiled by the authors.

\section{Results}

\section{Stage 1}

From the very start of our research, we identified a group of respondents who refused categorically to believe in the COVID-19 pandemic in Russia, claiming that the danger had been exaggerated or that it was all the invention of persons who stood to benefit ${ }^{7}$. In the first survey, one in four respondents $(26.3 \%)$ held this view. By the time of the seventh wave, despite the continuing spread of COVID-19 in Russia, this number had risen to $43.4 \%$. We termed this group of respondents COVID dissidents (COVID-D) and studied them over the course of six months.

Based on answers from the seven total samples, we generated two additional samples: (1) COVID-D ${ }^{8}$ and (2) respondents aware of people in their environment who were infected. To identify the distinctive behavioral strategies of COVID dissidents, we compared compliance with lockdown measures in these three groups in five of the surveys (waves 3-7). Complete data are provided in Appendix B. The comparison showed that COVID dissidents were two or more times less compliant with lockdown restrictions than respondents in the total sample and three or more times less than those aware of people in their environment who were infected with the virus.

\footnotetext{
7 In all seven waves, respondents were asked to choose the statement that best characterizes the current state of COVID-19 in Russia. There were nine possible answers: 1) the pandemic hasn't yet begun; 2) we are still in an early stage; 3 ) the pandemic is currently under way; 4) the pandemic is now peaking; 6) there won't be a pandemic: the danger has been exaggerated; 7) there won't be a pandemic: it's the invention of people who stand to benefit; 8) don't know; 9) other.

8 The COVID-D group includes respondents who answered the question on the current state of COVID-19 in Russia by saying there won't be a pandemic: answers 6 and 7 (see footnote 6).
} 
Thus, the respondents we regarded as COVID dissidents were not only those who deny the pandemic in Russia, but also those who do not comply with government lockdown restrictions.

\section{Stage 2}

In the second stage of our study, we formulated several hypotheses that were studied in all surveys after the first (Table 2). We created linear regression models to analyze hypotheses (H1)-(H7) based on the data obtained in surveys 2-7. The regression results are detailed in Appendix C.

We originally hypothesized that COVID dissidents were more likely to be young, male, live in small communities far from large metropolitan centers and have low economic status. However, when we included these variables in the regression equation for all six surveys, we found that these factors have virtually no bearing on COVID dissidence. Moreover, the distribution of respondents by age, economic status and size of community in groups of COVID dissidents who fear and do not fear infection matched that of the total sample throughout the period of study. It is true that the percentage of males among COVID dissidents was higher than in the total samples in the first and second waves, but the percentages evened out by the seventh wave. This is an indirect indication that when the infection first began to spread, women were more likely to believe that the pandemic was real due to fears for their health and the health of their families.

The regression models in Appendix C, based on the six waves of surveys, show that the hypothesized relevance of sex (H7), age (H5), economic status (H4) and size of community (H6) was not corroborated. For this reason, only three independent variables were used in the final regression models: personal risk of contracting COVID-19, trust in official statistics on the number of cases in Russia and attitude to self-isolation measures. Since $\mathrm{R}^{2}$ for linear regressions turned out to be low (about 0.3 ), it should be noted that the independent variable (variables) may be influenced by other factors.

First, the percentage of COVID dissidents among respondents who assessed their danger of infection as high (who fear infection) ${ }^{9}$ remained within a range of $1 \%-2 \%$ in all the surveys. In the group of respondents who assessed their danger of infection as low (who do not fear infection) ${ }^{10}$, the percentage of COVID dissidents rose from $63 \%$ in the first wave to $83.8 \%$ in the seventh wave of the study. Second, among COVID dissidents, initially one out of three respondents, and subsequently one out of two, assessed the risk that they and their families would be infected as low. It should be noted that over the six months covered by the study, the percentage of respondents who did not fear infection essentially doubled: from $12.5 \%$ to $23 \%$ of all those surveyed. Third, the Pearson correlation coefficient between people's assessment of the coronavirus situation in Russia and their assessment of their personal risk of being infected also steadily increased: from 0.381 in the first survey to 0.527 in the sixth.

\footnotetext{
9 Score of 8-10 on a scale of 10 in terms of the perceived danger of COVID-19 for oneself and one's family.

${ }^{10}$ Score of $0-3$ on a scale of 10 in terms of the perceived danger of COVID-19 for oneself and one's family.
} 
Thus, the lower the assessment people give of their personal risk of being infected, the more often they express the opinion that there is no pandemic, i.e., on a personal level they do not trust the official international position on the COVID-19 pandemic. Figure 1 compares growth in COVID dissidence with growth in the awareness that people in the environment are infected as well as with the percentage of COVID dissidents who do not fear infection.

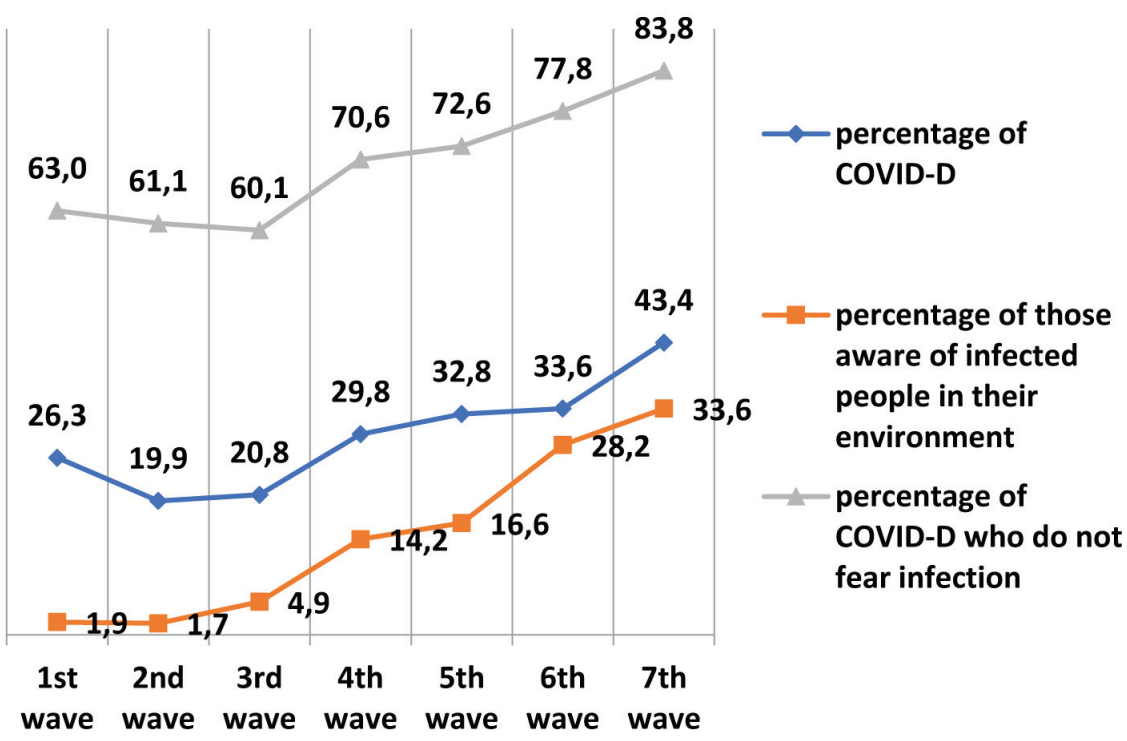

Figure 1. Comparison of growth in COVID-D with growth in the awareness that people in the environment are infected as well as with the percentage of COVID-D who do not fear infection, in percentage

To test hypotheses (H1)-(H3), we created six regression models, including one dependent variable - the attitude to COVID-19 in Russia - and three independent variables: assessment of personal risk of infection, trust in official statistics and attitude to self-isolation measures.

Table 3

\section{Linear regressions of factors associated with a level of COVID dissidence}

\begin{tabular}{|l|c|c|c|c|c|c|}
\hline & 2nd wave & 3rd wave & 4th wave & 5th wave & 6th wave & 7th wave \\
\hline Constant & 3.502 & 3.550 & 4.161 & 4.363 & 4.501 & 4.676 \\
\hline $\begin{array}{l}\text { Personal risk } \\
\text { of being infected }\end{array}$ & -0.206 & -0.211 & -0.231 & -0.204 & -0.197 & -0.178 \\
\hline $\begin{array}{l}\text { Attitude } \\
\text { to self-isolation }\end{array}$ & +0.386 & +0.410 & +0.378 & +0.349 & +0.307 & +0.327 \\
\hline $\begin{array}{l}\text { Trust in official } \\
\text { statistics }\end{array}$ & +0.172 & +0.164 & +0.157 & +0.167 & +0.201 & +0.151 \\
\hline
\end{tabular}

Source: Compiled by the authors. 
A comparison of the six regression equations shows that the constant increased, generally indicating that COVID dissidence grew during the spread of COVID-19 in Russia, as we have already noted. The coefficients of the dependent variables do not differ significantly and show an identical progression in all surveys. Our regression models demonstrate that people who have a low risk of being infected, who do not support self-isolation measures, and who believe that official data on the infection are inflated or that the number of cases are minimal, fall into the group of COVID dissidents. Hypotheses (H1), (H2) and (H3) were thus corroborated.

\section{Stage 3}

In the third stage of our study, we looked at how confidence that the public sector is competent in dealing with the problems caused by the pandemic is related to COVID dissidence. (H8): The less confidence people have that the public sector is competent to deal with the problems caused by COVID-19, the higher the level of COVID dissidence.

In stage 3, our study uses moderated mediation analysis to assess hypotheses H1, H2 and H3. Moderated mediation models are estimated using three ordinary least squares (OLS) regression equations. The equations used for moderate mediation differ from the standard approach in that they extend the standard regression (Table 3 ) by including a new interaction term in each. In stage 3 , we used citizens' attitudes to the level of the public sector's competence to control COVID-19 as such a term. Specifying the analysis in this way gives us a clearer idea of how one of the main indicators of basic trust can influence the appearance of COVID dissidence.

The frequency distribution, on a scale of 10 , of answers in waves 2-7 to the question "How confident are you that the problems caused by the spread of the pandemic in Russia will be solved within a month?" is shown in Figure 2:

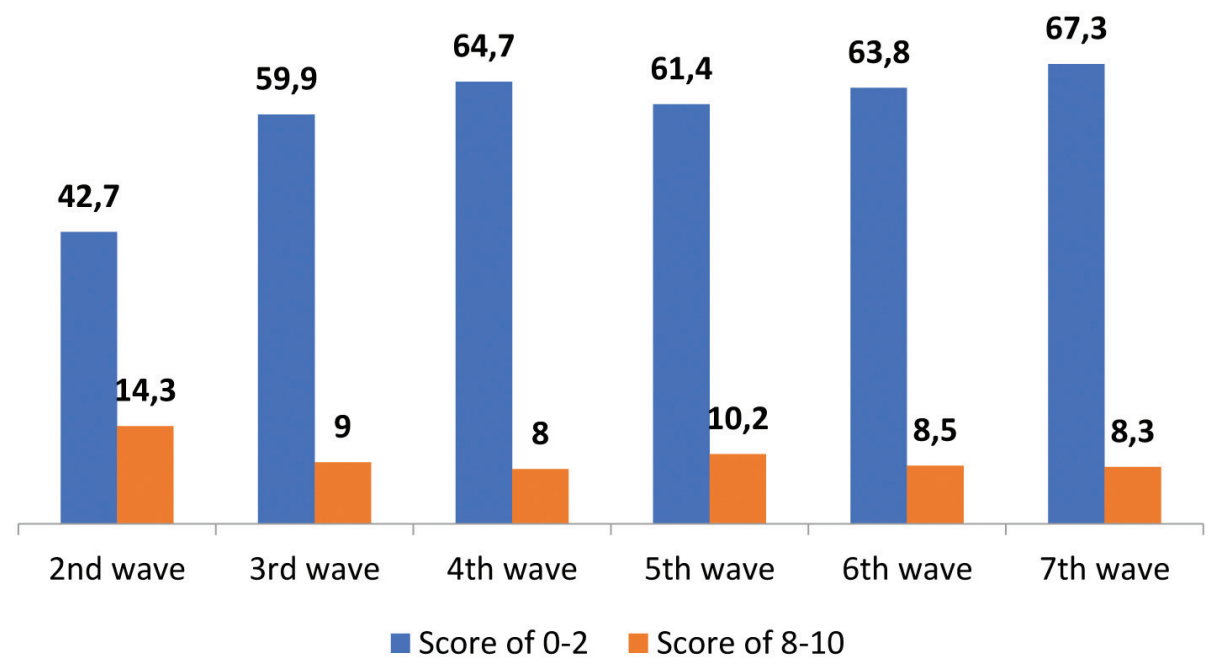

Figure 2. Distribution of positive (8-10) and negative (0-2) assessments of the public sector's competence in dealing with the problems caused by COVID-19, in percentage 
To obtain a variable for selecting observations, we combined the respondents' scores into three groups: scores of $0-3$ in the first group, 3-7 in the second, and $8-10$ in the third.

The new regression equations used to forecast the level of COVID dissidence for the group that gave a low assessment of the government's ability to control the spread of COVID-19 in Russia (a score of 0-2) are shown in Table 4.

Table 4

\section{Linear regressions}

\begin{tabular}{|l|c|c|c|c|c|c|}
\hline & 2nd wave & 3rd wave & 4th wave & 5th wave & 6th wave & 7th wave \\
\hline Constant & 3.730 & 3.742 & 4.181 & 4.380 & 4.556 & 5.416 \\
\hline $\begin{array}{l}\text { Personal risk } \\
\text { of being infected }\end{array}$ & -0.242 & -0.237 & -0.244 & -0.214 & -0.212 & -0.225 \\
\hline $\begin{array}{l}\text { Attitude to self- } \\
\text { isolation }\end{array}$ & +0.363 & +0.389 & 0.356 & +0.347 & +0.311 & +0.123 \\
\hline $\begin{array}{l}\text { Trust in official } \\
\text { statistics }\end{array}$ & +0.187 & +0.171 & +0.184 & +0.176 & +0.193 & +0.163 \\
\hline
\end{tabular}

Source: Compiled by the authors.

A comparison of the six new regressions (Table 4) with regression equations (Table 3) shows that the constant increased in all equations, and the coefficients of the independent variables follow the same trend in all surveys, increasing in the majority of cases. This confirms the general conclusion that people who do not believe that the public sector has the necessary competencies to control COVID-19 are more likely to become COVID dissidents. Hypothesis (H8) was thus corroborated.

\section{Stage 4}

In stage 4 , we used the data of individual surveys to study individual aspects of COVID dissidence.

In the second and third surveys, we hypothesized (H8-1) that distrust of the public sector's competence to control COVID-19 has to do with a lack of confidence that medical institutions where people live are prepared for the flow of patients. The Pearson correlation coefficient between these variables was 0.383 for the first wave and 0.345 for the second. Hypothesis (H7-1) was thus corroborated.

The fifth-wave survey included a special question about the efforts of federal, regional and municipal authorities to support individuals and the economy during the pandemic. Since there turned out to be a strong correlation between the assessments of various levels of government (a Pearson correlation coefficient of $0.663-0.852$ ), only one variable was used in the regression model: assessment of efforts at the federal level. Appendix D gives the values of the Pearson correlation coefficient with the given variable. In addition to the independent variables from the previously described regression models, two new variables were added: 
"managed to adapt to self-isolation" (correlation: 0.309) and "compliance with self-isolation"11 (correlation: -0.35).

We further hypothesized that COVID dissidents are more inclined to be critical of the public sector's efforts to support individuals and the economy during the COVID-19 pandemic (H9). To corroborate this hypothesis, we created a regression model including one dependent variable - assessment of the public sector's actions - and two new independent variables - compliance with self-isolation and adaptation to self-isolation - in addition to all the independent variables previously included in the full regression model.

By incrementally generating the regression equation, we established the following significant dependence:

Assessment of the public sector's actions $=2.506-0.087$ (attitude to self-isolation) - 0.301 (compliance with self-isolation) - 0.133 (impact of COVID-19 on spending $)+0.063$ (adaptation to self-isolation) (1)

The regression model (1) demonstrates that the more strongly people disagree with self-isolation restrictions and the less they comply with those restrictions, the lower their assessment of the public sector's actions. In contrast, the higher the level of people's adaptation to self-isolation, the higher their assessment of the public sector's actions. People who lost income during the pandemic also gave a lower assessment of the public sector's actions.

Thus, people who do not support self-isolation measures (74.2\% of COVID dissidents), who do not comply with restrictions and who have lost some or all of their income (54\% of COVID dissidents) are more likely to be critical of the public sector's efforts to support individuals and the economy during the pandemic.

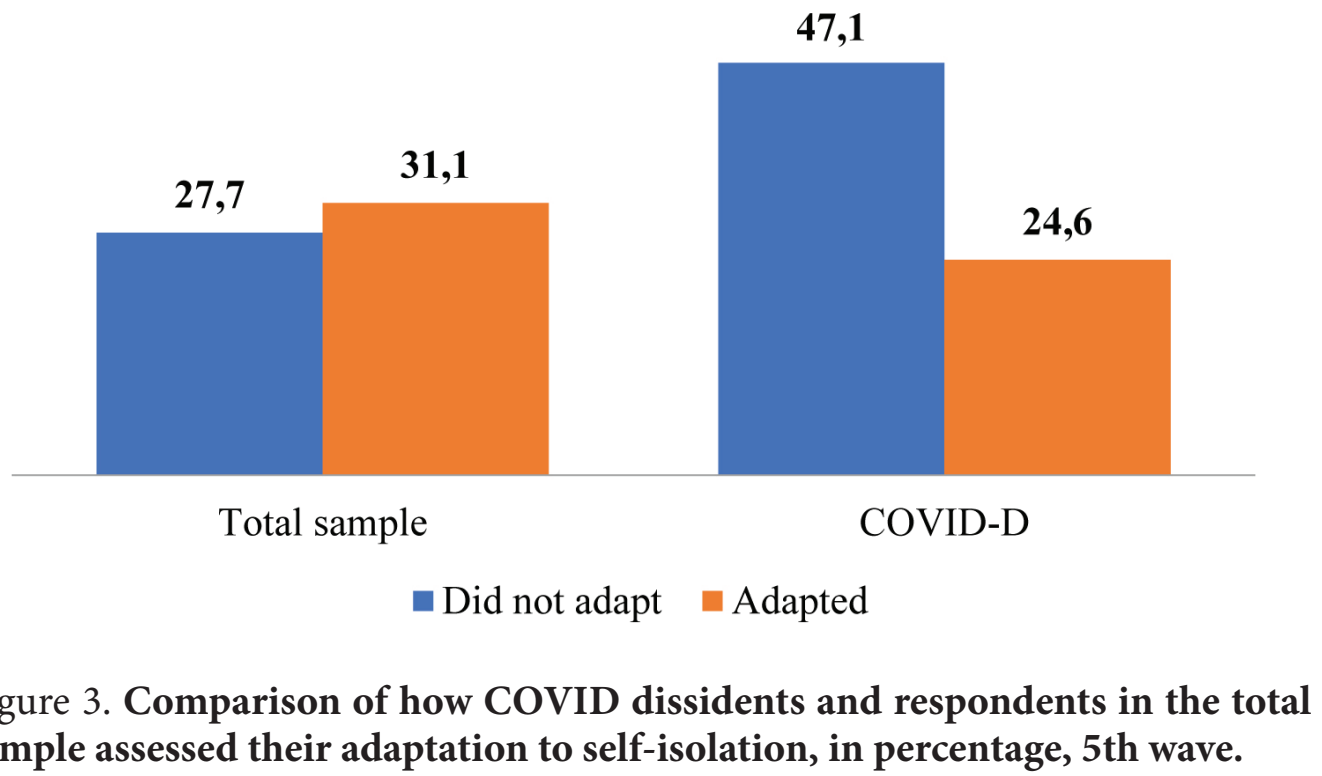

\footnotetext{
${ }^{11}$ A factor analysis was used to calculate this variable by determining the factor loading of all answers to the question "How have you changed your accustomed lifestyle during the coronavirus pandemic?"
} 
The sixth and last wave included two questions on the sources of COVID dissidence as perceived by COVID dissidents themselves: why they do not regard the virus as dangerous and what sources of information they base this on. A factor analysis was done based on the answers received. The results are detailed in Appendix E. The factor analysis showed that one out of five COVID dissidents has a conspiracy theory to explain COVID-19: it was created as a biological weapon, or to expand microchip implantation, or to alter the human genetic code, or to reduce the world's population, and so on. Ten percent of COVID dissidents believe that COVID-19 was invented by the authorities to distract people from important economic issues. Three other reasons (factors) for denying the COVID-19 pandemic have to do with (1) a lack of people in the respondent's environment who have contracted COVID-19 or had mild symptoms; (2) the perception of COVID-19 as a natural virus that does not result in fatalities, and (3) rumors and speculation, spread largely by social networks. Thus, in a situation where the authorities fail to adequately inform the public about the spread of the virus and the measures being taken, the information vacuum is filled by all sorts of unsubstantiated rumors and speculation and by distrust of official information.

Thus, hypotheses H1-H3, H8-H9 are accepted; H4-H7 are not supported.

\section{Discussion}

The current study applied the model used by Porumbescu (2016) to analyze how the use of social networks and websites is linked to trust in government. We confirmed that three criteria could be used to measure trust in government: citizens' opinion of public sector competence, their opinion of whether the public sector acts in the interests of citizens, and the public sector's faithfulness in living up to its public commitments. By including specific variables reflecting each of these three criteria in the model, we were able to identify the key factors influencing trust in government and also the specific conditions and forms of distrust of government as these relate to COVID dissidence in Russia.

Drawing on theoretical literature, international statistics and sociological studies, we demonstrated that trust in government is an important determinant of citizens' compliance with public health policies, especially in times of crisis. General international trends were corroborated by research done in Russia. Our study confirmed most of the similar hypotheses from international studies: a higher level of compliance to national directives is observed in regions with a high level of trust (Bargain and Aminjonov, 2020); general COVID-19 conspiracy theories negatively correlate with preventive behavior, while the belief that government was hiding the real number of COVID-19 cases is positively associated with protective measures (Oleksy et al., 2021); trust in public institutions positively predicts different types of precautionary behaviors, but these relationships are conditioned by knowledge about COVID-19 and extreme negative emotion (Min et al., 2020); and without trust in government or institutions, it is difficult to mobilize support for policy implementation, especially when short-term sacrifices are required in crisis situations (Kye and Hwang, 2020). 
Using the example of Russia, a country with a low level of trust in government institutions, we established that the higher the level of COVID dissidence, the more likely people are to disagree with self-isolation restrictions and the less likely they are to comply with lockdown measures. COVID dissidents are more inclined to be critical of the public sector's efforts to support individuals and the economy during the COVID-19 pandemic, and this group is much less compliant with self-isolation measures. It turns out that a high level of general distrust of public institutions results in an ever-growing group of COVID dissidents who violate government requirements, thus contributing to growth in the number of cases and to still greater distrust of government efforts to support individuals and the economy during the pandemic. This, in turn, further increases distrust of public institutions and non-compliance with government restrictions as well as the incidence of COVID-19 cases.

We were unable to corroborate the classic hypothesis advanced by many specific as well as general theoretical studies that an increase in the transparency and availability of information tends to improve the level of trust. It would be interesting, however, to look at what type of information, disseminated in what format, tends to promote opportunistic behavior and growth in COVID dissidence and what information, on the contrary, tends to promote social solidarity and reduce the level of COVID dissidence. It would also be interesting to see whether these processes are driven by any additional cultural, ethical, educational or other catalysts in countries with different levels of basic trust.

There are some limitations to this study. First, our study of the causal relationship between trust in government and COVID dissidents' behavior was conducted during the first wave of the pandemic. Second, we conducted our survey in Russia, whose government concentrates a lot of power, thus creating a unique political culture. We believe that extreme caution is needed in order to generalize the findings from our study and map them to other societies.

\section{Conclusions}

Our analysis demonstrated that COVID dissidence is not only a Russian, but a global phenomenon, and its dimensions in each country depend on the general level of trust in government: the lower the level of trust in government, the higher the level of citizens' non-compliance with lockdown restrictions. Our results also foreshadow the obstacles that some countries may face in order to convince citizens to get vaccinated once a vaccine is developed. In particular, vaccination rates may differ between countries depending on the level of public trust and perception of the effectiveness of government actions during the COVID-19 pandemic.

This study brings attention to a serious challenge that is faced by governments around the world, especially in countries with a low level of trust in public institutions. The lower the level of trust, the longer and harder the pandemic recovery is. The clearest confirmation of this conclusion is the new pandemic waves that are now covering the world. We believe that not only a vaccine but 
also serious efforts by national governments are needed to stop the pandemic, concentrating particularly on growing the level of public trust in their decisions and actions.

We recommend governments consider restoring citizens' trust as one of the priorities in fighting the pandemic, alongside battling misinformation that feeds conspiracy beliefs. Joint actions by media and government authorities could be effective in achieving trust in official government information. The Government should also provide more space for relevant scientific and statistical information.

We believe that the framework presented in the article can be further enhanced by comparing the results of economic recovery after the pandemic in groups of countries with different levels of trust in government. The pandemic crisis has had mixed impacts on social trust. Improvement in generalized social trust may also have a positive feedback to the risk management process because low social trust can exacerbate the consequences of the crisis (Kye and Hwang, 2020).

Maintaining variety in regional attitudes towards national policy makers continues to be important and should be taken into account by the authorities responsible for general policy design as well as by those responsible for the implementation of nationwide emergency policies. This is relevant to the current context for both the enforcement of lockdown policies and the necessity to recover from the crisis and economic downturn. Further research is needed to find a relationship between local or individual data on vaccination and compliance with anti-COVID restrictions. The research studies could go further to revealing the relationship between risk management processes and the level of public trust in various social groups.

\section{REFERENCES}

Achuo, E.D. (2020) 'How efficient are government stringency responses in curbing the spread of the covid-19 pandemic?' International Journal of Research and Innovation in Social Science, 4.

Aitalieva, N. (2018) 'Bureaucracy and Public Trust', in Ali Farazmand (ed.) Global encyclopedia of public administration, public policy, and governance. Springer.

Alessandro, M., Lagomarsino, B.C., Scartascini, C., Streb, J. and Torrealday, J. (2021) 'Transparency and Trust in Government. Evidence from a Survey Experiment', World Development, 138.

Alfano, V. and Ercolano, S. (2020) 'The efficacy of lockdown against COVID-19: A crosscountry panel analysis' Applied Health Economics and Health Policy. DOI: 10.1007/s40258020-00596-3. 
Allington, D., Duffy, B., Wessely, S., Dhavan, N. and Rubin, J. (2021) 'Health-protective behaviour, social media usage and conspiracy belief during the COVID-19 public health emergency', Psychological Medicine, 51(10), pp. 1763-1769.

Bachman, R. and Inkpen, A. (2011) 'Understanding institutional-based trust building processes in inter-organizational relationships', Organization Studies, 32(2), pp. 281-301.

Bargain, O. and Aminjonov, U. (2020) 'Trust and compliance to public health policies in times of COVID-19', Journal of Public Economics, 192, 104316.

Beck, U. (2000) Obshchestvo riska. Na puti k drugomu modernu [Risk society: On the way to another modern]. Moscow: Progress-Tradition (in Russian).

Bish, A. and Michie, S. (2010) 'Demographic and attitudinal determinants of protective behaviours during a pandemic: a review', Br. J. Health Psychol., 15 (4), pp. 797-824.

Blind, P. (2007) Building Trust in Government in the Twenty-First Century: Review of Literature and Emerging Issues. Seventh Global Forum on Reinventing Government, Building Trust in Government, Vienna, Austria, June 26-29. Available at: https://www.almendron.com/tribuna/wp-content/uploads/2016/11/building-trust-in-government-in-thetwenty-first-century.pdf (accessed 30 September 2021).

Bok, D. (1997) 'Measuring the Performance of Government', in Joseph S. Nye, Jr., Philip D. Zelikow and David C. King (eds). Why People Don't Trust Government. Cambridge, MA: Harvard University Press, pp. 55-75.

Buerhoff, H. and Vornefeld, B. (2016) 'The social psychology of trust with applications in the internet', Analyse and Kritik, 26 (1), pp. 48-62.

Christensen, T. and Laegreid, P. (2005) 'Trust in government: The relative importance of service satisfaction, political factors, and demography', Public Performance and Management Review, 28 (4), pp. 487-511.

Cullier, D. and Piotrowski, S. J. (2009) 'Internet information-seeking and its relation to support for access to government records', Government Information Quarterly, 26, pp. 441-49.

Enria, L., Waterlow, N., Rogers, N. T., Brindle, H., Lal, S., Eggo, R. M., Lees, S. and Roberts, C. (2020) Trust and transparency in times of crisis: Results from an online survey during the first wave (April 2020) of the COVID-19 epidemic in the UK. DOI: https://doi.org/ 10.1101/2020.09.01.20183822.

Freimuth, V.S., Musa, D., Hilyard, K., Quinn, S.C. and Kim, K. (2014) 'Trust during the early stages of the 2009 H1N1 pandemic', J. Health Commun., 19 (3), pp. 321-339.

Fukuyama, F. (2008) Doveriye. Sotsial'nyye dobrodeteli i put' k protsvetaniyu [Trust: Social virtues and the path to prosperity]. Moscow: AST (in Russian).

Grimmelikhuijsen, S. (2012) 'Linking transparency, knowledge and citizen trust in government: An experiment', International Review of Administrative Sciences, 78(1), pp: 50-73. 
Grimmelikhuijsen, S., Porumbescu, G., Hong, B. and Im, T. (2013) 'The effect of transparency on trust in government: A cross-national comparative experiment', Public Administration Review, 73, pp. 575-86.

Hardin, R. (1998) 'Trust in government', in V. Braithwaite and M. Levi (eds) Trust in Governance. Russell Sage Foundation, pp. 9-27.

Inglehart, R. (1997) 'Postmaterialist values and the erosion of institutional authority', in J. S. Nye, Jr., P. Zelikow and D. King (eds) Why people don't trust government. Cambridge, MA: Harvard University Press, pp. 217-36.

Ipsen C., Myers A. and Sage R. (2021) 'A cross-sectional analysis of trust of information and COVID-19 preventative practices among people with disabilities', Disability and Health Journal, 14(2). Available at: https://doi.org/10.1016/j.dhjo.2021.101062.

Jaeger, P. and Bertot, J. (2010) 'Transparency and technological change: Ensuring equal and sustained public access to government information', Government Information Quarterly, 27(4), pp. 371-76.

Kim, S.-E. (2005) 'The role of trust in the modern administrative state: An integrative model', Administration \& Society, 37(5), pp. 611-35.

Kye B. and Hwang Sun-Jae (2020) 'Social trust in the midst of pandemic crisis: Implications from COVID-19 of South Korea', Research in Social Stratification and Mobility, 68.

Levy, M. and Stoker, L. (2000) 'Political trust and trustworthiness', Annual Review of Political Science, 3, pp. 375-407.

Mansoor M. (2021) 'Citizens' trust in government as a function of good governance and government agency's provision of quality information on social media during COVID-19', Government Information Quarterly, in press.

Michener, G. and Bersch, K. (2013) 'Identifying transparency', Information Polity, 18 (3), pp. 233-42.

Min, C., Shen, F., Yu, W. and Chu, Y. (2020) 'The relationship between government trust and preventive behaviors during the COVID-19 pandemic in China: Exploring the roles of knowledge and negative emotion', Preventive Medicine,141. Available at: https://doi. org/10.1016/j.ypmed.2020.106288.

Nooteboom, B. (2007) 'Social capital, institutions and trust', Review of Social Economy, 65 (1), pp. 29-53.

OECD (2017a) OECD Guidelines on Measuring Trust. Paris: OECD Publishing. Available at: http://dx.doi.org/10.1787/9789264278219-en.

OECD (2017b) Trust and public policy: How better governance can help rebuild public trust. Paris: OECD Publishing. Available at: http://dx.doi.org/10.1787/9789264268920-en.

O'Hara, L., Rahim, H. F. A. and Shi, Z. (2020) Gender and trust in government modify the association between mental health and stringency of social distancing related public health measures to reduce COVID-19: a global online survey. Available at: https://doi.org/10.1101/ 2020.07.16.20155200. 
Oleksy, T., Wnuk, A., Gambin, M. and Ły's, A. (2021) 'Dynamic relationships between different types of conspiracy theories about COVID-19 and protective behaviour: A fourwave panel study in Poland', Social Science \& Medicine, 280.

Porumbescu, G. (2016) 'Linking public sector social media and e-government website use to trust in government', Government Information Quarterly, 33 (2), pp. 291-304.

Rainey, H. (1997) Understanding and managing public organizations. 2d ed. San Francisco, CA: Jossey-Bass Publishers.

Seligman, A. (2002) Problema doveriya [The problem of trust]. Moscow: Idea-Press (in Russian).

Sztompka, P. (2012) Doveriye - osnova obshchestva [Trust is the foundation of society]. Moscow: Logos (in Russian).

Thomas, C.W. (1998) 'Maintaining and restoring public trust in government agencies and their employees', Administration and Society, 30 (2), pp. 166-93.

Ticlău, T., Hintea, C. and Andrianu, B. (2020) 'Adaptive and turbulent governance. Ways of governing that foster resilience. The case of the COVID-19 pandemic', Transylvanian Review of Administrative Sciences. Special Issue, pp. 167-182.

Tolbert, C. and Mossberger, K. (2006) 'The effects of e-government on trust and confidence in government', Public Administration Review, 66(3), pp. 354-69.

Uslaner, E. (2008) 'The foundations of trust: Macro and micro', Cambridge Journal of Economics 32(2) (March 2008), pp. 289-94.

Warren A.M., Sulaiman A. and Jaafar N.I. (2014) 'Social media effects on fostering online civic engagement and building citizen trust and trust in institutions', Government Information Quarterly 31(2), pp. 291-301.

Wirawan, G.B.S., Mahardani, P.N.T.Y., Cahyani, M.R.K., Laksmi, N.L.P.S.P. and Januraga, P.P. (2021) 'Conspiracy beliefs and trust as determinants of COVID-19 vaccine acceptance in Bali, Indonesia: Cross-sectional study', Personality and Individual Differences, 180.

Zucker, L.G. (1986) 'Production of trust: Institutional sources of economic structure, 1840-1920’, Research in Organizational Behavior, 8, pp. 53-111. 


\section{Appendix A. National levels of trust and growth in the number of cases after restrictions (lockdown measures) are lifted}

\begin{tabular}{|c|c|c|c|c|c|}
\hline No & Country & $\begin{array}{l}\text { Trust } \\
\text { in government } \\
\text { according } \\
\text { to the Edelman } \\
\text { Trust Barometer } \\
\quad 2020\end{array}$ & $\begin{array}{l}\text { Duration } \\
\text { of lockdown, } \\
\text { days }\end{array}$ & $\begin{array}{l}\text { Growth } \\
\text { in the number } \\
\text { of cases } 10 \text { days } \\
\text { after restrictions } \\
\text { are lifted }\end{array}$ & $\begin{array}{l}\text { Growth } \\
\text { in the number } \\
\text { of cases } 20 \text { days } \\
\text { after restrictions } \\
\text { are lifted }\end{array}$ \\
\hline 1 & China & 90 & 58 & $0.1 \%$ & $0.1 \%$ \\
\hline 2 & India & 81 & 32 & $6.5 \%$ & $6.6 \%$ \\
\hline 3 & Saudi Arabia & 78 & 94 & $3.3 \%$ & $2.9 \%$ \\
\hline 4 & $U A E$ & 76 & 46 & $4.9 \%$ & $4.3 \%$ \\
\hline 5 & Indonesia & 75 & 127 & $1.6 \%$ & $1.5 \%$ \\
\hline 6 & Singapore & 70 & 59 & $3.5 \%$ & $2.8 \%$ \\
\hline 7 & Thailand & 60 & 76 & $0.1 \%$ & $0.1 \%$ \\
\hline 8 & Netherlands & 59 & 49 & $0.9 \%$ & $0.7 \%$ \\
\hline 9 & Malaysia & 58 & 84 & $0.3 \%$ & $0.2 \%$ \\
\hline 10 & Canada & 50 & 46 & $2.9 \%$ & $2.3 \%$ \\
\hline 11 & Germany & 45 & 38 & $1.0 \%$ & $0.8 \%$ \\
\hline 12 & Mexico & 44 & 107 & $2.1 \%$ & $2.0 \%$ \\
\hline 13 & Australia & 44 & 53 & $0.1 \%$ & $0.2 \%$ \\
\hline 14 & Japan & 43 & 54 & $0.2 \%$ & $0.3 \%$ \\
\hline 15 & Italy & 41 & 36 & $1.7 \%$ & $1.3 \%$ \\
\hline 16 & Ireland & 41 & 52 & $0.3 \%$ & $0.2 \%$ \\
\hline 17 & USA & 39 & 42 & $2.7 \%$ & $2.3 \%$ \\
\hline 18 & Brazil & 37 & 27 & $9.1 \%$ & $8.1 \%$ \\
\hline 19 & $U K$ & 36 & 45 & $1.7 \%$ & $1.3 \%$ \\
\hline 20 & France & 35 & 55 & $0.3 \%$ & $0.4 \%$ \\
\hline 21 & Argentina & 34 & 80 & $4.5 \%$ & $4.8 \%$ \\
\hline 22 & Russia & 33 & 42 & $3.5 \%$ & $2.9 \%$ \\
\hline 23 & Columbia & 33 & 62 & $4.8 \%$ & $4.3 \%$ \\
\hline 24 & Spain & 30 & 37 & $2.2 \%$ & $1.9 \%$ \\
\hline 25 & South Africa & 20 & 36 & $6.0 \%$ & $6.0 \%$ \\
\hline
\end{tabular}

Sources: Compiled by the authors. 


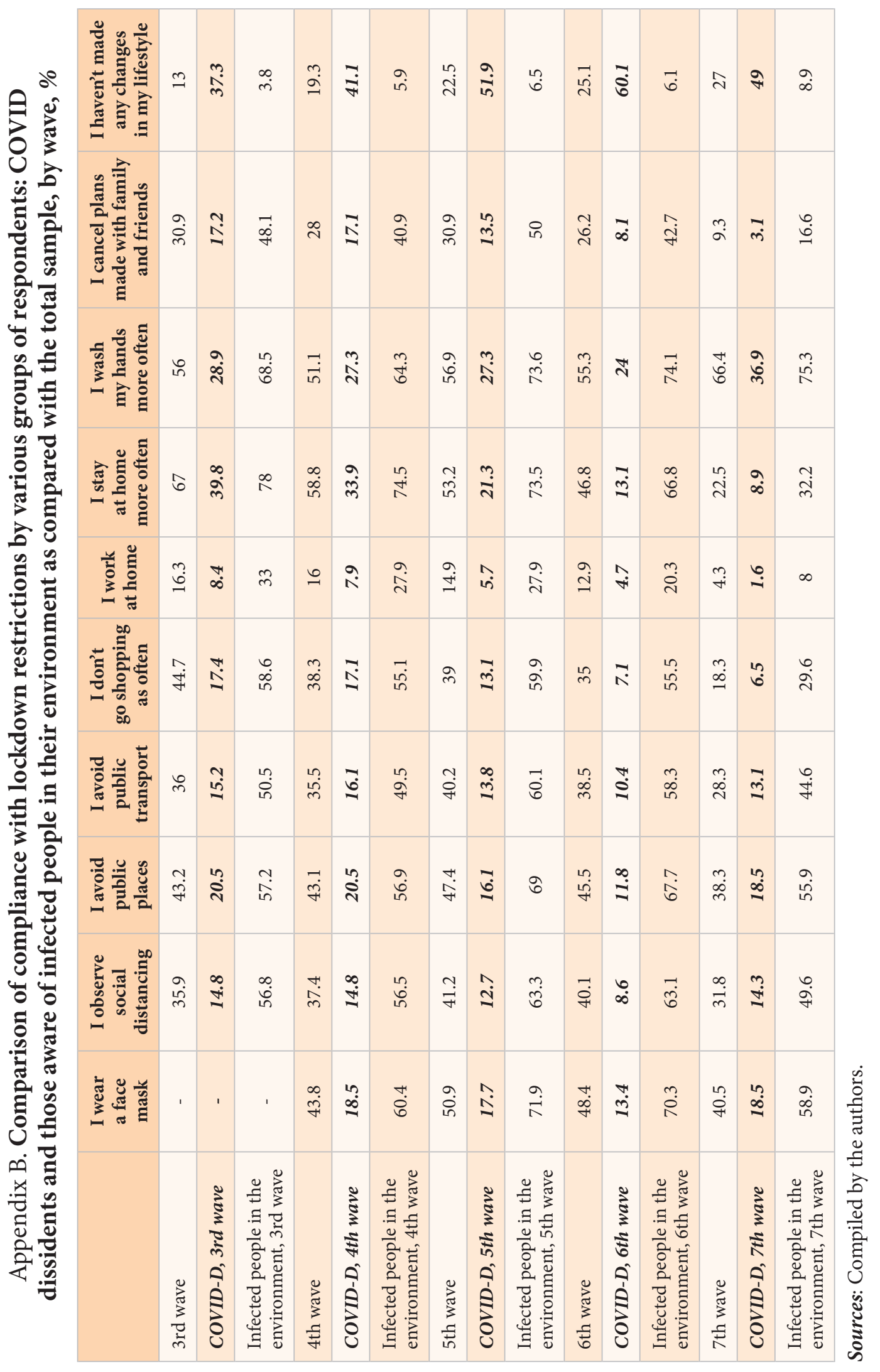




\section{Appendix C. Regression results of the fully specified model in stage 2}

\begin{tabular}{|l|c|c|c|c|c|c|}
\hline & $\begin{array}{c}\text { Second } \\
\text { wave }\end{array}$ & $\begin{array}{c}\text { Third } \\
\text { wave }\end{array}$ & $\begin{array}{c}\text { Fourth } \\
\text { wave }\end{array}$ & $\begin{array}{c}\text { Fifth } \\
\text { wave }\end{array}$ & $\begin{array}{c}\text { Sixth } \\
\text { wave }\end{array}$ & $\begin{array}{c}\text { Seventh } \\
\text { wave }\end{array}$ \\
\hline $\mathrm{R}^{2}$ & 0.285 & 0.313 & 0.359 & 0.332 & 0.374 & 0.263 \\
\hline Durbin-Watson & 2.050 & 1.993 & 2.005 & 2.014 & 2.013 & 2.014 \\
\hline Attitude to personal risks of infection & -0.203 & -0.211 & -0.234 & -0.206 & -0.202 & -0.212 \\
\hline Attitude to self-isolation & 0.372 & 0.395 & 0.363 & 0.339 & 0.302 & 0.136 \\
\hline Trust in official statistics & 0.172 & 0.163 & 0.157 & 0.165 & 0.200 & 0.155 \\
\hline Sex & -0.169 & -0.073 & -0.035 & -0.035 & 0.035 & 0.006 \\
\hline Size of community & 0.042 & -0.007 & -0.059 & -0.020 & 0.012 & 0.029 \\
\hline Age & 0.087 & 0.051 & 0.081 & 0.069 & 0.013 & 0.041 \\
\hline Economic status & -0.042 & -0.083 & -0.050 & -0.033 & 0.015 & -0.034 \\
\hline Impact of COVID-19 on income & 0.046 & 0.043 & 0.037 & 0.035 & 0.048 & - \\
\hline Impact of COVID-19 on spending & 0.005 & -0.005 & - & - & \\
\hline
\end{tabular}

Sources: Compiled by the authors.

\section{Appendix D. Bivariate correlations ${ }^{13}$ at stage 3}

\begin{tabular}{|c|c|c|c|c|c|c|c|c|}
\hline & 1 & 2 & 3 & 4 & 5 & 6 & 7 & 8 \\
\hline $\begin{array}{l}\text { Assessment of the } \\
\text { public sector's actions } \\
\text { (1) }\end{array}$ & 1 & & & & & & & \\
\hline $\begin{array}{l}\text { Assessment of the } \\
\text { public sector's } \\
\text { competence }(2)\end{array}$ & $0.296^{* *}$ & 1 & & & & & & \\
\hline $\begin{array}{l}\text { Attitude to personal } \\
\text { risks of infection ( } 3 \text { ) }\end{array}$ & $0.304^{\star *}$ & $0.079^{\star *}$ & 1 & & & & & \\
\hline $\begin{array}{l}\text { Trust in official } \\
\text { statistics (4) }\end{array}$ & $0.036^{* *}$ & $0.074^{\star *}$ & $-0.284^{\star *}$ & 1 & & & & \\
\hline $\begin{array}{l}\text { Impact of COVID-19 } \\
\text { on income (5) }\end{array}$ & $-0.229^{\star \star}$ & $-0.063^{\star *}$ & $-0.101^{\star *}$ & 0.012 & 1 & & & \\
\hline $\begin{array}{l}\text { Attitude to self- } \\
\text { isolation (6) }\end{array}$ & $-0.280^{\star *}$ & $-0.041^{\star *}$ & $-0.461^{\star *}$ & $0.297^{\star *}$ & $0.127^{\star *}$ & 1 & & \\
\hline $\begin{array}{l}\text { Compliance with self- } \\
\text { isolation (7) }\end{array}$ & $-0.356^{\star *}$ & $-0.101^{\star *}$ & $-0.529^{\star *}$ & $0.195^{\star *}$ & $0.090^{* *}$ & $0.418^{\star *}$ & 1 & \\
\hline $\begin{array}{l}\text { Managed to adapt } \\
\text { to self-isolation (8) }\end{array}$ & $0.309^{* *}$ & $0.169^{* *}$ & $0.227^{\star *}$ & $-0.076^{* *}$ & $-0.254^{* *}$ & $-0.266^{\star *}$ & $-0.213^{\star *}$ & 1 \\
\hline
\end{tabular}

Sources: Compiled by the authors.

12 In the seventh survey, this question was formulated a little differently: "If there is a second wave, how fully will you comply with self-isolation measures?"

$13 * \star$ Significance level of 0.01 (two-tailed). 


\section{Appendix E. Results of factor analysis, sixth wave}

\section{Rotation matrix of components $\mathrm{s}^{\mathrm{a}}$}

\begin{tabular}{|c|c|c|c|c|c|}
\hline & \multicolumn{5}{|c|}{ Component } \\
\hline & 1 & 2 & 3 & 4 & 5 \\
\hline Explained aggregate dispersion, \% & 22.247 & 10.240 & 8.228 & 7.643 & 7.419 \\
\hline $\begin{array}{l}\text { The authorities are to blame for the } \\
\text { emergence of COVID-19 }\end{array}$ & -.015 & .763 & -.005 & .008 & .123 \\
\hline $\begin{array}{l}\text { A global shadow government is to blame } \\
\text { for the emergence of COVID- } 19\end{array}$ & .643 & -.047 & -.063 & -.131 & -.149 \\
\hline $\begin{array}{l}\text { Pharmaceutical companies are to blame } \\
\text { for the emergence of COVID-19 }\end{array}$ & .391 & .268 & .184 & .273 & .053 \\
\hline $\begin{array}{l}\text { No one in my environment has contracted } \\
\text { COVID-19 }\end{array}$ & .088 & .257 & -.739 & .198 & -.293 \\
\hline $\begin{array}{l}\text { No one in my environment has died from } \\
\text { COVID-19 }\end{array}$ & .141 & .366 & -.277 & .549 & -.226 \\
\hline $\begin{array}{l}\text { Everyone I know who was infected had only } \\
\text { mild symptoms }\end{array}$ & .080 & .171 & .810 & .167 & -.256 \\
\hline $\begin{array}{l}\text { I have heard/read that COVID-19 is not } \\
\text { dangerous }\end{array}$ & .091 & .123 & -.017 & .040 & .879 \\
\hline $\begin{array}{l}\text { COVID-19 developed naturally without } \\
\text { human involvement }\end{array}$ & -.184 & -.330 & .118 & .738 & .155 \\
\hline $\begin{array}{l}\text { COVID-19 was created as a biological } \\
\text { weapon }\end{array}$ & .535 & .141 & .075 & -.178 & -.067 \\
\hline $\begin{array}{l}\text { COVID- } 19 \text { was created for purposes } \\
\text { of selling the vaccine }\end{array}$ & .593 & .252 & .037 & .184 & .060 \\
\hline $\begin{array}{l}\text { COVID- } 19 \text { was created to expand microchip } \\
\text { implantation }\end{array}$ & .691 & .120 & -.058 & .031 & .096 \\
\hline $\begin{array}{l}\text { COVID-19 was created to alter the human } \\
\text { genetic code }\end{array}$ & .658 & -.030 & -.044 & .104 & .057 \\
\hline $\begin{array}{l}\text { COVID-19 was created to distract people } \\
\text { from current economic issues }\end{array}$ & .260 & .662 & -.022 & -.099 & -.007 \\
\hline $\begin{array}{l}\text { COVID- } 19 \text { was created to reduce the world's } \\
\text { population }\end{array}$ & .700 & .091 & .021 & -.061 & .064 \\
\hline
\end{tabular}

Notes: Factoring method: principal components.

Rotation method: varimax with Kaiser normalization.

a. Eight iterations per rotation.

Sources: Compiled by the authors.

The article was submitted: 05.04.2021; approved after reviewing: 27.09.2021; accepted for publication: 28.11.2021. 